\title{
Using osteological measurements to estimate body length in Amazonian manatees
}

\author{
Gisele de Castro Maciel VALDEVINO ${ }^{1 *}$, Vera Maria Ferreira DA SILVA ${ }^{1}$, Rodrigo de Souza AMARAL ${ }^{2}$ \\ IInstituto Nacional de Pesquisas da Amazônia - INPA, Laboratório de Mamíferos Aquáticos, Avenida André Araújo 2936, CEP 69.067-375, Manaus, AM, Brazil \\ ${ }^{2}$ Instituto Federal de Educação, Ciência e Tecnologia do Amazonas - IFAM, Campus Manaus Zona Leste, Avenida Cosme Ferreira 8045, CEP 69.086-475, Manaus, AM, Brazil \\ *Corresponding author: gmaciel88@gmail.com; (D) https://orcid.org/0000-0001-9664-449X
}

\section{ABSTRACT}

Body length is an important parameter in morphological, ecological and behavioral studies of a species and contributes to the understanding of the body condition of individuals. This parameter is essential for conservation and management strategies by informing studies evaluating growth rates, physical maturity and classification of individuals into age groups, promoting better accuracy for the biological parameters of the species. The aim of this study was to identify predictors of body length for Amazonian manatees (Trichechus inunguis) using metric characters of osteological materials. Eleven linear measurements of skull, jaw, scapulae and humeri were collected from 41 Amazonian manatee skeletons of different age classes (calf, juvenile and adult). Data were analyzed by simple linear regression. The condylobasal length was the best predictor of body length for the species $(\mathrm{R}=0.943)$, however, all bones evaluated showed at least one measurement with the capacity to predict body size $\left(\mathrm{R}^{2}\right.$ $>0.9)$. Results of this study are useful for inferring body length of Amazonian manatees using bones deposited in museums and biological collections, expanding the informative potential of these materials.

KEYWORDS: Sirenia, morphometry, collections, osteological material

\section{Utilização de medidas osteológicas para estimativa de comprimento corporal em peixe-boi da Amazônia}

\section{RESUMO}

O comprimento corporal é um importante parâmetro em estudos morfológicos, ecológicos e comportamentais de uma espécie e contribui para o entendimento da condição corporal de um indivíduo. Este parâmetro é essencial para estratégias de conservação e manejo, informando estudos que avaliam taxas de crescimento, maturidade física e classificação dos indivíduos em grupos de idade, promovendo uma melhor precisão aos parâmetros biológicos de uma espécie. O objetivo desse trabalho foi identificar preditores de comprimento corporal para o peixe-boi da Amazônia (Trichechus inunguis) utilizando caracteres métricos de material osteológico. Onze medidas lineares do crânio, mandíbula, escápula e úmero foram coletadas de 41 esqueletos de peixe-boi da Amazônia de diferentes classes de idade (filhote, juvenil e adulto). Os dados foram analisados por regressão linear simples. O comprimento côndilobasal foi o melhor preditor de comprimento corporal para a espécie $(\mathrm{R}=$ 0,943), entretanto, todos os ossos avaliados mostraram pelo menos um caractere com capacidade de predizer o comprimento corporal $\left(\mathrm{R}^{2}>0,9\right)$. Os resultados deste estudo são úteis para inferir o comprimento corporal de peixes-boi da Amazônia a partir de ossos depositados em museus e coleçóes biológicas, expandindo o potencial informativo destes materiais.

PALAVRAS-CHAVE: Sirenia, morfometria, coleção, material osteológico

\section{INTRODUCTION}

Body length is an important parameter in morphological, ecological and behavioral studies of a species (Amaral et al. 2010) and essential for determining growth curves and age categorizations (Hildebrandt et al. 2007; Mumby et al. 2015). Additionally, body length is used for the analysis of the body condition of individuals, helping the management and conservation of numerous species of mammals (Rosas et al. 2009). Therefore, body length should be evaluated as accurately as possible given its use in ecological interpretations (Rosas et al. 2009; Sarko et al. 2010).

Several studies have shown efficacy in predicting body length based on morphometric characteristics in aquatic mammals, (Sousa-Lima and Groch 2010; Calderón et al. 2018), including correlations of skull bones or other bones with body length (Itoo and Inoué 1993; Perrin et al. 2005; Sarko et al. 2010; Castelblanco-Martinez et al. 2014; Churchill et al. 2014; Danilewicz 2018). 
Among sirenians, body lengths of dugongs (Dugong dugon Müller, 1776) have been estimated from cranial measurements by Spain and Heinsohn (1974), Sarko et al. (2010) and Nganvongpanit et al. (2017). Both Sarko et al. (2010) and Castelblanco-Martinez et al. (2014) estimated body length using skull measurements for Florida manatees (Trichechus manatus latirostris Harlam, 1824) and Antillean manatees (Trichechus manatus manatus Linnaeus, 1758), respectively, and demonstrated the strong relationship between cranial measurements and body length for these species. Nganvongpanit et al. (2017) evaluated the use of mandible and scapular measurements in addition to cranial measurements to predict total length in dugongs, and observed lower correlations of mandible and scapular structures to body length compared with those of cranial measurements. Although this body length estimation technique has been validated in different sirenian species, as shown by Sarko et al. (2010), there are no reports of body length estimates for Amazonian manatees (Trichechus inunguis Natterer, 1883) using bone measurements, and none of these existing equations have been applied to Amazonian manatees.

The Amazonian manatee is the smallest sirenian and the only species that occurs exclusively in freshwater (Rosas 1994). Predatory hunting of Amazonian manatees, although illegal, currently persists throughout its distribution and, consequently, it is common to find incomplete skeletons deposited in biological collections (Rosas 1994; Franzini et al. 2013; Souza 2015). Thus, important biological information, such as gender and body length, frequently cannot be determined accurately (Vergara-Parente et al. 2010), preventing the use of these specimens in studies of population structure and hunting pressure, for example. Therefore, this study aimed to identify predictors of body length for Amazonian manatees using different bones available in biological collections.

\section{MATERIAL AND METHODS}

We measured skeletons from 41 Amazonian manatees (calves, juveniles and adults), with body lengths from $62.8 \mathrm{~cm}$ to 257 $\mathrm{cm}$, deposited in the aquatic mammal collection under the supervision of the Aquatic Mammal Laboratory of Instituto Nacional de Pesquisas da Amazônia (INPA), Manaus, Brazil. Body length data (measured in a straight line from the tip of the snout to the tip of the fluke) were available for all the specimens analyzed. However, most specimens did not have complete skeletons, thus, 29 skulls (14 $\hat{O}$ and 15 P), 41 mandibles (21 $\hat{\partial}$ and 20 P), 33 scapulae (18 $\hat{\partial}$ and 15 + ) and 22 humeri (13 $\delta^{\lambda}$ and 9 P ) were measured. Since Amazonian manatees do not present sexual dimorphism (Domning and Hayek 1986; Amaral et al. 2010), data from both sexes were combined and analyzed together.
All materials were measured by one researcher (GCMV) with a TIN $300 \mathrm{~mm}$ analog Digimess caliper, São Paulo, SP, Brazil. Skull and jaw measurements were obtained according to Domning and Hayek (1986) and Sarko et al. (2010). Measurements of humeri and scapulae followed Ali et al. (2016) and Nganvongpanit et al. (2017). Linear measurements of the bones are presented in Figure 1 with associated acronyms in Table 1. Paired bones (humeri and scapulae) were compared with paired $t$-tests to assess whether measurements of the right or left side can be used interchangeably. The relationship between body length (BL) and each measured parameter was obtained by simple linear regression. Subsequently, the parameters in each bone with high correlation to total length (adjusted $\mathrm{R}^{2}>0.9$ ) were reanalyzed by multiple linear regression. All statistical analyses were performed using R Program version 4.0.2 (2020-06-22) from The R Foundation for Statistical Computing.
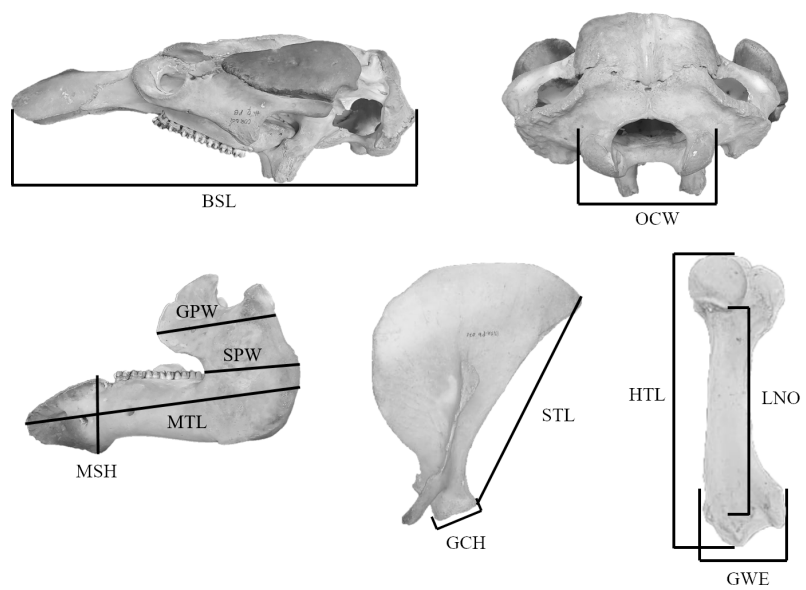

Figure 1. Linear measurements of skull, mandible, scapula and humerus of Amazonian manatees, Trichechus inunguis used in this study. Acronyms are defined in Table 1.

Table 1. Linear measurements of the bones of Amazonian manatees, Trichechus inunguis analyzed in this study.

\begin{tabular}{|c|c|c|}
\hline Category & Acronym & Description \\
\hline \multirow{2}{*}{ Skull } & BSL & Condylobasal skull length \\
\hline & OCW & Occipital condyle width \\
\hline \multirow{4}{*}{ Mandible } & MTL & Anteroposterior mandible length \\
\hline & SPW & Shortest length of the ascending branch \\
\hline & GPW & Greatest length of the ascending branch \\
\hline & $\mathrm{MSH}$ & Mandibular symphysis height \\
\hline \multirow[t]{2}{*}{ Scapula } & STL & $\begin{array}{c}\text { Greatest length between caudal angle and edge of } \\
\text { the glenoid cavity }\end{array}$ \\
\hline & $\mathrm{GCH}$ & Glenoid cavity width \\
\hline \multirow{3}{*}{ Humerus } & HTL & Humeri total length \\
\hline & LNO & $\begin{array}{l}\text { Length between the anatomical neck of the humerus } \\
\text { and the olecranon fossa edge }\end{array}$ \\
\hline & GWE & $\begin{array}{c}\text { Greatest width between the lateral epicondyle and } \\
\text { medial epicondyle }\end{array}$ \\
\hline
\end{tabular}




\section{RESULTS}

The scapulae and humeri showed no significant difference between the right and left sides for all measurements $(\mathrm{P}>$ 0.05 ; paired $t$-test; $\mathrm{n}=22$ scapulae and 22 humeri). Thus, we used the average of measurements from both sides. Only two specimens lacked one humerus and radius each, and measurements from the existing side were used.

Of the variables analyzed in this study, the condylobasal length (BSL) was the parameter that showed the highest correlation coefficient (Table 2; Figure 2). However, the other bones showed at least one measurement with a high capacity

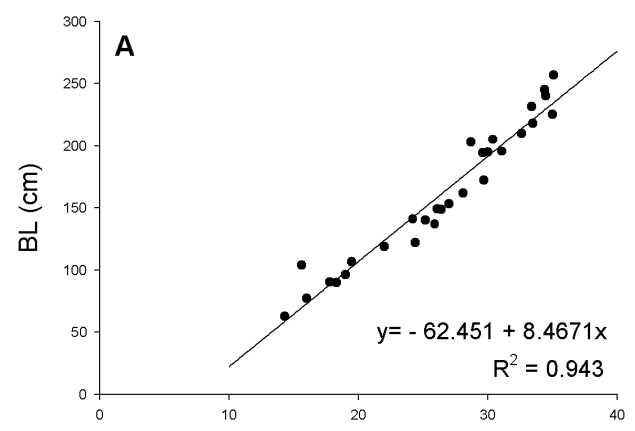

$\mathrm{BSL}(\mathrm{cm})$
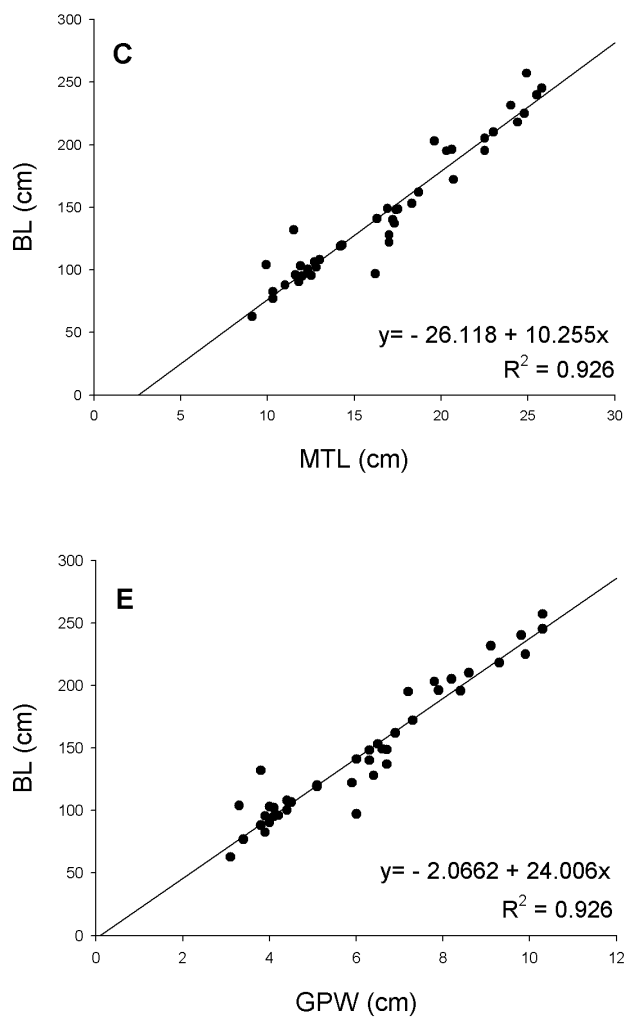

(adjusted $\left.\mathrm{R}^{2}>0.9\right)$ to predict body length in the Amazonian manatee (mandible: MTL, SPW, and GPW; scapulae: STL; and humeri: GWE) (Table 2; Figures 2 and 3).

Multiple linear regression using BSL, MTL, SPW, GPW, LNO and STL presented an adjusted correlation value of $\mathrm{R}^{2}$ $=0.961(\mathrm{p}>0.0001)$ and a residual value of 17.5 using the following equation:
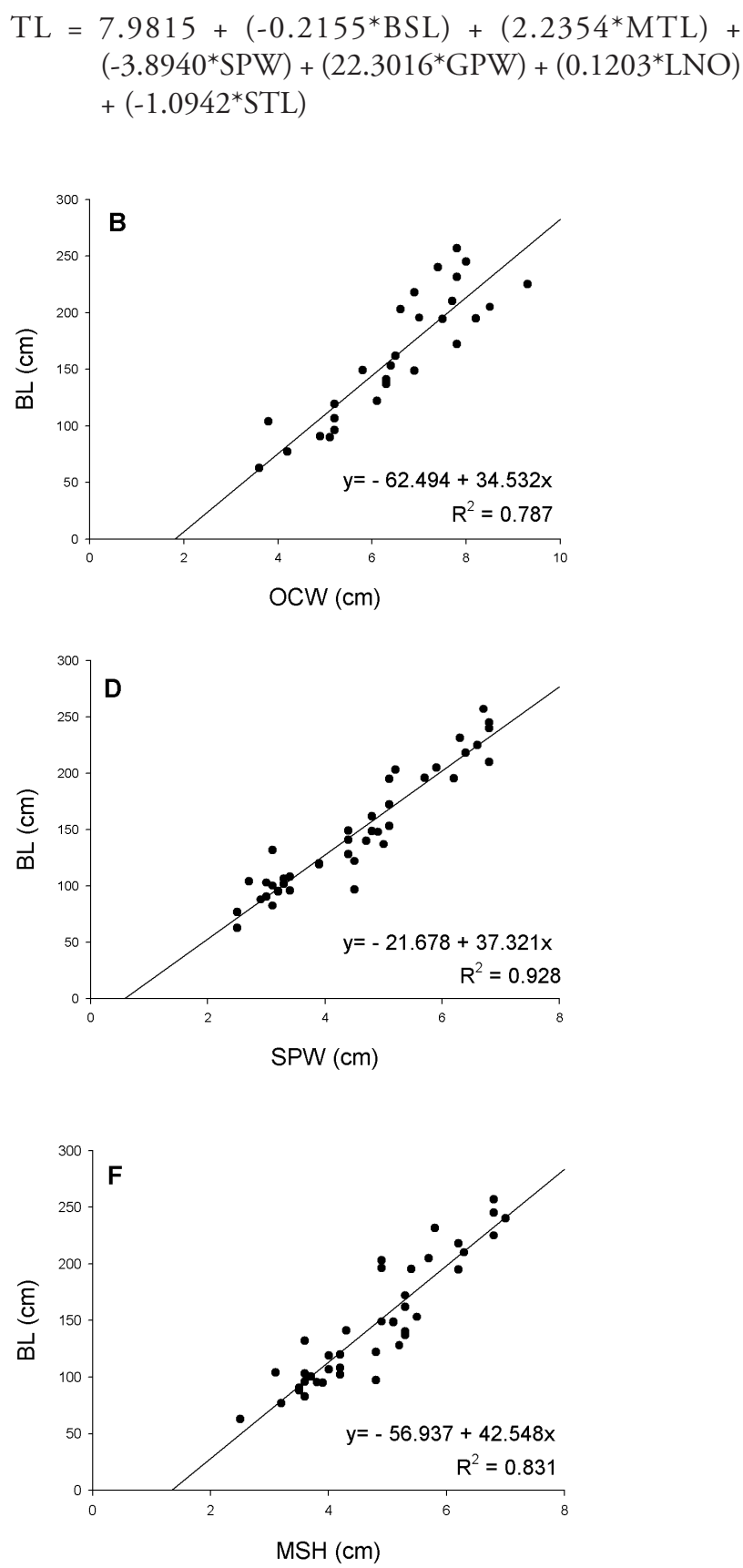

Figure 2. Relation of cranial measurements with body length (BL) of 41 specimens of Amazonian manatees, Trichechus inunguis deposited in the aquatic mammal collection of INPA (sample size varies according to availability of body parts). A and B - Skull: condylobasal skull length (BSL) and occipital condyle width (OWC); C, $D, E$, and F - Mandible: anteroposterior mandible length (MTL), shortest length of the ascending branch (SPW), greatest length of the ascending branch (GPW), and mandibular symphysis height (MSH). The lines were fitted by linear regression. Regression equations and adjusted $\mathrm{R}^{2}$ values are shown as inserts. 
Table 2. Statistical values resulting from the linear regression and multiple regression of bone measurements on body length of Amazonian manatees, Trichechus inunguis.

\begin{tabular}{lcccc}
\hline Bone measurement & Regression model & $R^{2}$ adjusted & $p$ & $\begin{array}{c}\text { \% residue value in } \\
\text { percentile } 90\end{array}$ \\
\hline Skull & & & & \\
BSL & $y=-62.451+8.4671 x$ & 0.943 & $<0.001$ & 11.7 \\
OWC & $y=-62.494+34.532 x$ & 0.787 & $<0.001$ & 21.5 \\
Mandible & & & 15.7 \\
MTL & $y=-26.118+10.255 x$ & 0.926 & $<0.001$ & 19.8 \\
SPW & $y=-21.678+37.321 x$ & 0.928 & $<0.001$ & 15.8 \\
GPW & $y=-2.0662+24.006 x$ & 0.926 & $<0.001$ & 25.3 \\
MSH & $y=-56.937+42.548 x$ & 0.831 & $<0.001$ & 29.3 \\
SCapula & & & & 32.8 \\
STL & $y=10.333+12.971 x$ & 0.915 & $<0.001$ & 35 \\
GCH & $y=58.821-22.931 x$ & 0.766 & $<0.001$ & 15.3 \\
Humerus & $y=18.38+12.26 x$ & 0.873 & & 13 \\
\hline HTL & $y=-14.302+17.865 x$ & 0.880 & $<0.001$ & \\
LNO & $y=-10.132+45.001 x$ & 0.921 & $<0.001$ & \\
GWE & & &
\end{tabular}
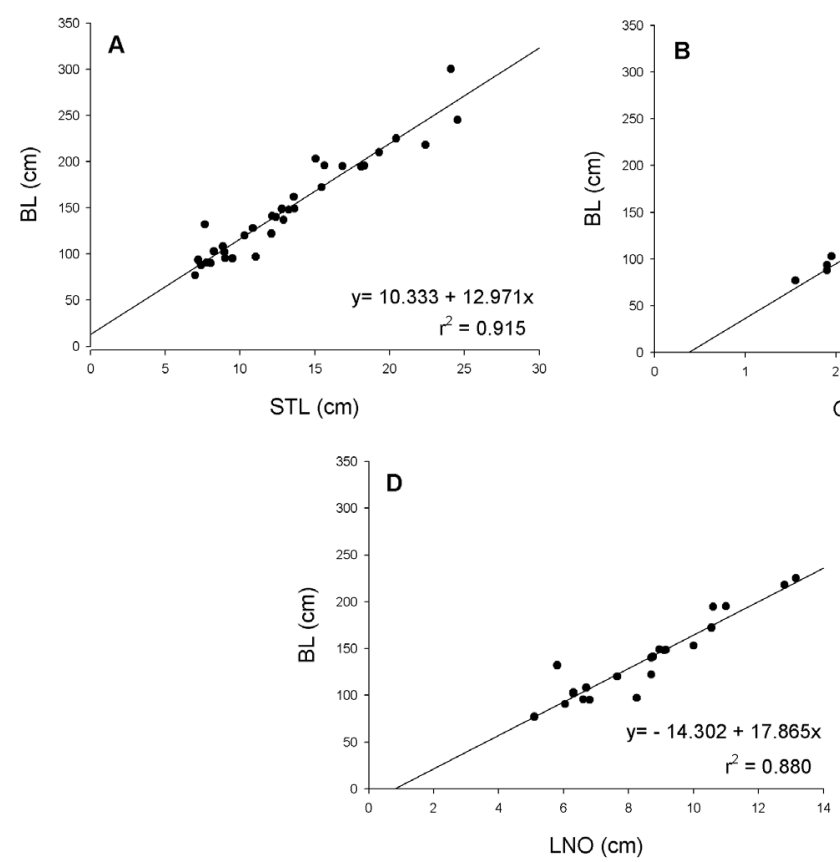
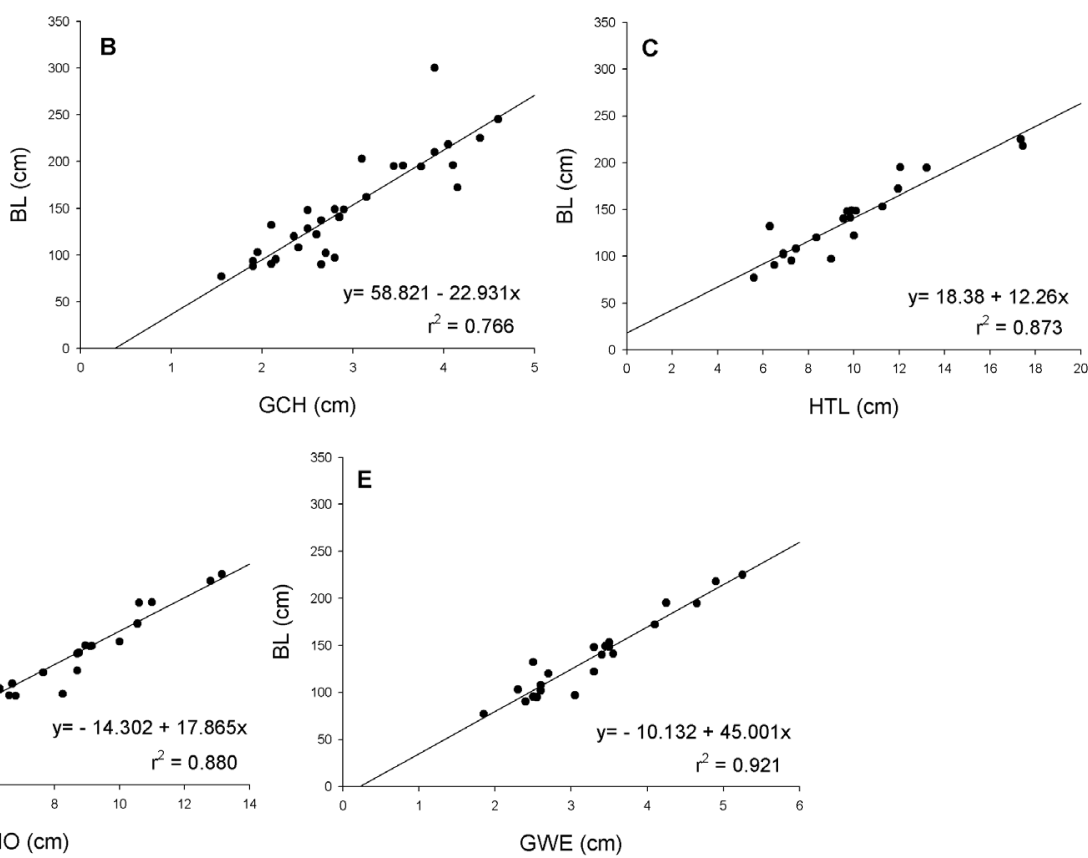

Figure 3. Relation of the linear measurements of the forelimb with body length (BL) of 41 specimens of Amazonian manatees, Trichechus inunguis deposited in the aquatic mammal collection of INPA (sample size varies according to availability of body parts). A and B - Scapula: greatest length between the caudal angle and edge of the glenoid cavity (STL) and glenoid cavity width (GCH); C, D, and E - Humerus: humerus total length (HTL), length between the anatomical neck of the humerus and the olecranon fossa edge (LNO), greatest width between the lateral epicondyle and medial epicondyle (GWE). Regression equations and adjusted $R^{2}$ values are shown as inserts.

\section{DISCUSSION}

In this study, the condylobasal length (BSL) was the parameter that best estimated body length of Amazonian manatees. This measurement has also been described as an excellent predictor of body length in other orders of aquatic mammals, such as pinnipeds (Churchill et al. 2014) and cetaceans (Perrin 1975). Castelblanco-Martinez et al. (2012) also observed a high correlation between condylobasal length and body length in T. m. manatus, as did Sarko et al. (2010) for T. m. latirostris and D. dugon and Spain (1974) for D. dugon, supporting our results for Amazonian manatees.

The use of mandible measurements to estimate body length in mammals has been reported for manatees, pinnipeds, cetaceans and several terrestrial mammals (Domning and 
Hayek 1986; Nummela et al. 2004; Churchill et al. 2014; Stansfield 2015). In T. inunguis, development of the mandible and its structures can be correlated with the physical maturity of the animal. Domning and Hayek (1986) described ontogenetic variations in morphometric parameters of the mandible, including the parameters used in the present study (anteroposterior mandible length and mandibular symphysis height). Although these studies did not directly correlate morphometric measurements with the individual body lengths, mandible ontogenetic variation described in Domning and Hayek (1986) supports the effective prediction of body length found in our study when using these mandibular measurements.

Nganvongpanit et al. (2017) used linear measurements of $D$. dugon scapulae to estimate body length in this species, showing that both cranial and scapulae measurements were good predictors of body size in dugongs. In the present study, we used two scapulae measurements used by Nganvongpanit $e t$ al. (2017), and the scapulae total length (STL) was satisfactory in determining body length in Amazonian manatees.

The relationship between width of the lateral and medial humeral epicondyles and body length of Amazonian manatees observed in our study may be related to occurrence of pachyostosis in the bones of some tetrapods secondarily adapted to aquatic life (de Buffrénil et al. 2010). The proximal portion of the humerus of Amazonian manatees becomes quite robust as the animal develops, with the medial epicondyle being markedly broader than the lateral epicondyle, making this bone region quite large when compared to the rest of the structure.

Although multiple linear regression showed a high predictive ability for body length, it is not a practical tool to estimate body length since it requires the presence of a skull, a mandible, scapulae and humeri from the same individual in the osteological collection. Therefore, considering the high $\mathrm{R}^{2}$ values obtained in this study, we recommend the independent use of the skull (BSL), humerus (GWE), mandible (MTL, GPW or SPW) or scapula (STL) measurements, in that order, to provide a better estimate of the body length of the Amazonian manatee.

Considering the lack of body length records in a significant number of specimens deposited in biological collections and the imprecise records of individual body lengths, the equations obtained in this study may be useful to estimate these important biological data. For example, VergaraParente et al. (2010) had to use an imprecise body length measurement (estimated using the palmos length of a hunter's hand, converted to $21.71 \mathrm{~cm}$ ) to calculate growth curves for the Amazonian manatees. This imprecision could be reduced using one of the equations presented herein. Additionally, these results can be used in future studies to evaluate growth rates, physical maturity and classification of individuals into age groups, promoting a better accuracy for the biological parameters of the species.

\section{CONCLUSIONS}

Our results indicate that it is possible to use morphometric measurements of skull, humerus, mandible or scapula to estimate the body length of Amazonian manatees when the whole skeleton is not available. Among the parameters evaluated, the condylobasal length was the best predictor of body length.

\section{ACKNOWLEDGMENTS}

We thank Coordenação de Aperfeiçoamento de Pessoal de Nível Superior (CAPES) for supplying a scholarship to GCMV. We are also grateful to Petrobras Socioambiental (Projeto Mamíferos Aquáticos da Amazônia) and Associação Amigos do Peixe-boi (AMPA) for their financial support of the activities of Laboratório de Mamíferos Aquáticos (LMA/INPA).

\section{REFERENCES}

Amaral, R.S.; da Silva, V.M.F.; Rosas, F.C.W. 2010. Body weight/ length relationship and mass estimation using morphometric measurements in Amazonian manatee Trichechus inunguis (Mammalia: Sirenia). Marine Biodiversity Records, 3: e105.

Best, R.C. 1984. The aquatic mammals and reptiles of the Amazon. In: Sioli, H. (Ed.). The Amazon, Limnology and Landscape Ecology of a Mighty Tropical River and its Basin. Springer Netherlands, Dordhecth, p.371-412.

Calderón, M.G.; da Silva, V.M.F.; Barnett, A.A.; Martin, A.R. 2018. Estimating the length of dolphins using photographs where another animal of known or estimated length is in close proximity. Marine Mammal Science, 34: 1111-1118.

Castelblanco-Martínez, D.N.; Morales-Vela, B.; Padilla-Saldívar, J.A. 2014. Using craniometrical predictors to infer body size of Antillean manatees. Mammalia, 78: 109-115.

Churchill, M.; Clementz, M.T.; Kohno, N. 2014. Predictive equations for the estimation of body size in seals and sea lions (Carnivora: Pinnipedia). Journal of Anatomy, 225: 232-245.

De Buffrénil, V.; Canoville, A.; D’Anastasio, R.; Domning, D.P. 2010. Evolution of sirenian pachyosteosclerosis, a model-case for the study of bone structure in aquatic tetrapods. Journal of Mammal Evolution, 17: 101-120.

Domning, D.P.; Hayek, L.A.C. 1986. Interspecific and intraspecific morphological variation in manatees (Sirenia, Trichechus). Marine Mammal Science, 2: 87-144.

Franzini, A.M.; Castelblanco-Martínez, D.N.; Rosas, F.C.W.; da Silva, V.M.F. 2013. What do local people know about Amazonian manatees? Traditional ecological knowledge of Trichechus inunguis in the oil province of Urucu, AM, Brazil. Brazilian Journal of Nature Conservation, 11: 75-80.

Hildebrandt, T.; Drews, B.; Gaeth, A.P.; Goeritz, F.; Hermes, R.; Schmitt, D.; et al. 2007. Foetal age determination and development in elephants. Proceedings of the Royal Society B, 274: 323-331. 
Mumby, H.S.; Chapman, S.N.; Crawley, J.A.H.; Mar, K.U.; Htut, W.; Soe, A.T.; Aung, H.H.; Lummaa, P. 2015. Distinguishing between determinate and indeterminate growth in a long-lived mammal. BMC Evolutionary Biology, 15: 214. doi.org/10.1186/ s12862-015-0487-x

Nummela, S.; Kosove, J.E.; Lancaster, T.E.; Thewissen, J.G.M. 2004. Lateral mandibular wall thickness in Tursiops truncatus: variation due to sex and age. Marine Mammal Science, 20: 491-497.

Rosas, F.C.W. 1994. Biology, conservation and status of the Amazonian Manatee Trichechus inunguis. Mammal Review, 24: 49-59.

Rosas, F.C.W.; Rocha, C.S.; Mattos, G.E.; Lazzarini, S.M. 2009. Body weight-length relationships in giant otters (Pteronura brasiliensis) (Carnivora, Mustelidae). Brazilian Archives of Biology and Technology, 52: 587-591.

Sarko, D.K.; Domning, P.D.; Marino, L.; Reep, R.L. 2010. Estimating body size in fossil sirenians. Marine Mammal Science, 26: 937-959.
Sousa-Lima, R.S.; Groch, K.R. 2010. Correlation between body length and fluke width in humpback whales, Megaptera novaeangliae. Marine Mammal Science, 26: 977-981.

Souza, D.A. 2015. Peixe-boi da Amazônia (Trichechus inunguis NATTERER 1883): Mortalidade e uso do habitat na Reserva de Desenvolvimento Sustentável Piagaçu-Purus, Amazonas, Brasil. Master's thesis, Instituto Nacional de Pesquisas da Amazônia, Brazil, 133p. (https://bdtd.inpa.gov.br/handle/tede/2150). Accessed on 19 Mar 2021.

Stansfield, F.J. 2015. A novel objective method of estimating the age of mandibles from African elephants (Loxodonta africana). PLoS ONE 10: e0124980.

Vergara-Parente, J.E.; Parente, C.L.; Marmontel, M.; Silva, J.C.R.; Sá, F.B. 2010. Growth curve of free-ranging Trichechus inunguis. Biota Neotropica, 10: 89-92.

RECEIVED: 09/11/2020

ACCEPTED: $15 / 02 / 2021$

ASSOCIATE EDITOR: Paulo D. Bobrowiec 